\title{
Wpływ BIZ na kreowanie wartości dodanej w kraju goszczącym ze szczególnym uwzględnieniem przetwórstwa przemysłowego
}

\section{The Impact of FDI on Gross Value Added in Host Country with Particular Emphasis on Manufacturing Sector}

Streszczenie: Znaczenie bezpośrednich inwestycji zagranicznych dla wzrostu gospodarczego w krajach je goszczących jest tematem często poruszanym przez badaczy, aczkolwiek uzyskiwane przez nich wyniki empiryczne nie dają klarownego wytłumaczenia zjawiska. Podejmowane są liczne próby estymacji efektów obecności kapitału zagranicznego w gospodarce kraju goszczącego w wymiarze wzrostu gospodarczego, poprawy efektywności gospodarowania zasobami, wzrostu zatrudnienia i płac, transferu wiedzy i technologii. Niniejsze opracowanie wpisuje się w nurt, zgodnie z którym wpływ obecności BIZ (Bezpśrednich Inwestycji Zagranicznych) na gospodarkę należy rozpatrywać w ujęciu sekcji wg klasyfikacji PKD (lub na poziomie pojedynczych podmiotów), co pozwala na dokładniejsze oszacowanie efektów w poszczególnych przypadkach niż prezentacja efektu netto w skali makroekonomicznej. W badaniu postanowiono sprawdzić na przykładzie polskiej gospodarki, na ile efekty obecności BIZ w sektorze przetwórczym są zbliżone do tych na poziomie makro. Posłużono się w tym celu danymi rocznymi za lata 1997-2012 oraz wykorzystano techniki modelowania szeregów czasowych z uwzględnieniem testowania stacjonarności i kointegracji. Uzyskane wyniki badań wskazują na istotne znaczenie obecności kapitału zagranicznego zarówno dla gospodarki, jak i dla przemysłu przetwórczego, przy czym zauważalna jest silniejsza zależność drugiej relacji. Nie bez znaczenia jest fakt, że pozytywne efekty BIZ w przypadku gospodarki ujawniają się po dwóch okresach, a w przypadku przemysłu przetwórczego już po jednym. Testy kointegracji potwierdziły występowanie długookresowej relacji pomiędzy zaangażowaniem kapitału zagranicznego w gospodarce (w przetwórstwie przemysłowym) a wartością dodaną brutto w gospodarce (w przetwórstwie przemysłowym) ${ }^{1}$.

Abstract: The impact of Foreign Direct Investment on economic growth in host economies has been widely researched however empirical results are still inconclusive. There exist numerous attempts to estimate the effects of FDI on the host economy in terms of economic growth, improvement of resource efficiency utilizing, employment and wages growth, transfer of knowledge and technology. This study complies with new trend that assume that the impact of the presence of FDI on the economy should be analyzed on sector, industry or even firm level, which allows for a more accurate estimates in individual

${ }^{1}$ Publikację sfinansowano z grantu uczelnianego na Badania Młodych Naukowców oraz Uczestników Studiów Doktoranckich Uniwersytetu Ekonomicznego w Krakowie, 118/WZ-SD/07/2015/M/5118. 
cases instead of presenting net effect at the macroeconomic level. In the study we decided to check on the example of Polish economy to what extent the effects of the presence of FDI in the manufacturing sector are similar to those at the macro level. We use for this purpose the annual data for the years 1997-2012, and time series modeling techniques, taking into account OLS regression, stationarity tests and cointegration. The obtained results indicate the importance of the presence of foreign capital for the economy as well as the manufacturing where a noticeable relationship is stronger in the second case. Not without significance is the fact that the positive effects of FDI occure in case of the economy after 2 periods, and in the case of manufacturing in one period. Cointegration tests confirmed the existence of a long-term relationship between FDI in the economy (in the sector) and GVA in the economy (in the sector).

Słowa kluczowe: BIZ; kointegracja, sektor produkcyjny; VECM

Keywords: cointegration; FDI; manufacturing sector; VECM

Otrzymano: 10 stycznia 2016

Received: 10 January 2016

Zaakceptowano: 24 marca 2016

Accepted: 24 March 2016

\section{Sugerowana cytacja / Suggested citation:}

Wojciechowski, L. (2016). Wpływ BIZ na kreowanie wartości dodanej w kraju goszczącym ze szczególnym uwzględnieniem przetwórstwa przemysłowego. Prace Komisji Geografii Przemysłu Polskiego Towarzystwa Geograficznego, 30(1), 143-158

\section{WSTĘP}

Polska jest liderem na rynku pozyskiwania bezpośrednich inwestycji zagranicznych (BIZ) wśród krajów, które przystąpiły do Unii Europejskiej po 2004 roku. Jednocześnie, jak pokazują najnowsze dane, dzięki napływowi BIZ na poziomie 13,9 mld dol. w 2015 roku Polska znalazła się na liście 20 największych odbiorców tych inwestycji na świecie (World Investment Report 2015, 2015). Według danych Eurostatu w $2012^{2}$ roku łączna wartość BIZ w Polsce według klasyfikacji NACE wyniosła $178878 \mathrm{mln}$ euro, z czego $56624 \mathrm{mln}$ $(31,7 \%)$ stanowiły inwestycje z sekcji C ,przetwórstwo przemysłowe ${ }^{3 \%}$, na które składały się głównie: ,produkcja artykułów spożywczych, napojów i wyrobów tytoniowych, wytwarzanie i przetwarzanie koksu i produktów rafinacji ropy naftowej, chemikaliów i wyrobów chemicznych oraz farmaceutycznych, a także wyrobów z gum i tworzyw sztucznych, a także wyrobów metalowych i maszyn, jak i pojazdów samochodowych i przyczep". Na koniec 2012 roku 891 spośród 1469 firm inwestujących w Polsce (ponad 60\%) podejmowało działalność w sektorze produkcyjnym. Dotyczyło to podmiotów zarówno z Unii Europejskiej, jak i z krajów poza Wspólnotą.

\footnotetext{
${ }^{2}$ Najnowsze dostępne dane.

${ }^{3}$ Pozyskano z http://ec.europa.eu/eurostat/ramon/nomenclatures/index.cfm?TargetUrl=DSP_NOM_DTL_ VIEW\&StrNom=NACE_REV2\&StrLanguageCode=PL\&IntPcKey $=\& I n t K e y=18496334 \&$ StrLayoutCode $=$ HIERARCHIC\&IntCurrentPage $=1$
} 


\section{PRZEGLĄD BADAŃ EMPIRYCZNYCH NA TEMAT WPŁYWU BIZ NA GOSPODARKĘ} KRAJU GOSZCZĄCEGO

Wpływ bezpośrednich inwestycji zagranicznych na gospodarki krajów goszczących często badany był przez pryzmat zmian produktywności. Prowadzone są analizy na różnych poziomach agregacji (makroekonomiczne, sektorowe). Gospodarka Polska stanowiła przedmiot zainteresowań wielu badaczy (m.in. Żukowska-Gagelman, 2000; Konings, 2001; Sgard, 2001; Dijankow, Hoeckman, 2000; Javorcik, 2004; Ciołek, Golejewska, 2006). Przyjmuje się, że efekt netto (różnice pomiędzy pozytywnymi i negatywnymi efektami) wpływu BIZ na gospodarkę kraju goszczącego jest uwarunkowany szeregiem czynników, takich jak: zdolność absorbcyjna (Girma, Görg, 2003; Kolasa, 2007), luka technologiczna (Ciołek, Golejewska, 2005; Ciołek, Golejewska, 2006; Ciołek, Umiński, 2007) czy charakterystyka kraju inwestora (Javorcik, 2004).

Międzynarodowa współpraca ekonomiczna stanowi jeden z kluczowych elementów determinujących sytuację społeczno-gospodarczą. Obecność kapitału zagranicznego w formie BIZ prowadzić może w warunkach odpowiednio wykształconych zdolności absorbcyjnych gospodarki do pozytywnego wpływu na m.in. dochody ludności, kwalifikacje pracownicze i popyt wewnętrzny. Obecność BIZ w gospodarce kraju goszczącego implikuje powiększenie wartości całkowitego kapitału, który z kolei determinuje poziom globalnej produkcji oraz oddziałuje na technologię. Z technologii korzystają jednak nie tylko firmy będące inwestorami zagranicznymi, ale też lokalne - w drodze efektów zewnętrznych (Szczepkowska-Flis, 2006; Szczepkowska-Flis, 2008). Literatura przedmiotu w zakresie mierzenia wpływu BIZ na produktywność przedsiębiorstw krajowych jest bogata. Biorąc pod uwagę dostępność relatywnie krótkich szeregów czasowych, Ciołek i Umiński (2007) postulowali wykorzystanie analizy panelowej w regresji BIZ względem wydajności pracy, produktywności majątku oraz Total Factor Productivity (TFP) przedsiębiorstw krajowych. W świetle ich badań obecność kapitału zagranicznego w branży w latach 1993-2004 wpływała mobilizująco na przedsiębiorstwa krajowe, co przejawiało się szybszym wzrostem TFP, aczkolwiek pozytywny wpływ BIZ ulegał osłabieniu lub nawet stawał się negatywny wraz z upływem czasu.

Golejewska (2009), posługując się danymi panelowymi, podjęła próbę oceny wpływu BIZ na sektor przetwórczy w Polsce w latach 1993-2007, testując hipotezę luki technologicznej (ang. technology gap) oraz zarażania (ang. contagion effect). Uzyskane wyniki wskazują na to, że nie występowały istotne pozytywne efekty spillover w rozważanym okresie. Jednocześnie wielkość luki technologicznej oddziaływała negatywnie na intensywność tych efektów. Rezultaty były różne od uzyskanych przez Żukowską-Gagelmann (2000) dla polskich firm przetwórczych w latach 1993-1997 oraz wcześniejszych badań autorki (Ciołek, Golejewska, 2006) w badaniu panelowym za lata 1993-2002. Sugeruje to, że efekty oddziaływania kapitału zagranicznego na gospodarkę kraju goszczącego nie muszą być stałe w czasie ani co do siły, ani kierunku oddziaływania.

Odnosząc się bezpośrednio do przemysłu przetwórczego, należy odnotować, że lokalizacja działalności w regionach determinowana jest przez różne czynniki związane zarówno z indywidualną specyfiką poszczególnych regionów, jak i charakteryzujące różne branże. 
Analizy przeprowadzone przez Brodzickiego i Ciołek $(2010$; 2014) wskazują na istotną rolę wielkości rynku regionu mierzonego jego populacją oraz poziomem infrastruktury dla lokalizacji przemysłu przetwórczego. Ponadto zauważają oni, że sektory przemysłu o wyższej intensywności wiedzy lokują się w regionach z bardziej rozbudowaną bazą badawczo-rozwojową. W polskiej literaturze spotkać można liczne próby estymacji zależności pomiędzy BIZ a wzrostem gospodarczym (Pawłowska, Wojciechowski, 2015; Marona, Bieniek, 2013; Balcerzak, Żurek, 2010; Gurgul i Lach, 2009). Autorzy sięgają przeważnie po techniki modelowania szeregów czasowych (VAR, VECM) oraz panelowych.

W literaturze światowej nie ma zgody co do wpływu BIZ na gospodarkę kraju goszczącego. Frey (1992) wskazywał na negatywne związki pomiędzy BIZ i wzrostem gospodarczym, podczas gdy Hassan (2004), Carkovic i Levine (2002) stwierdzali brak statystycznie istotnej zależności. Z kolei m.in. w pracach Chonga i in. (2010) czy Samini i in. (2010) potwierdzono występowanie pozytywnej zależności między BIZ a wzrostem gospodarczym. Praca Alfaro (2003) rzucała nowe spojrzenie na rozważane zjawisko. Założył on, że BIZ nie wpływa na wszystkie sektory w ten sam sposób, doszukując się heterogeniczności zjawiska, a tym samym poddał w wątpliwość analizy przeprowadzane na poziomie makroekonomicznym. Wyniki badań empirycznych dotyczące wpływu BIZ na poszczególne sektory są niejednoznaczne i wysoce wrażliwe na dobór próby, zakres czasowy i rozważane aproksymanty obecności kapitału zagranicznego i wymiaru, w jakim rozpatrywany jest wzrost gospodarczy. Masron i in. (2012) stwierdzają, że wpływ BIZ na wzrost gospodarczy w sektorze przetwórczym za sprawą transferu technologii i innych efektów zewnętrznych jest mocno dyskusyjny. Warto również odnieść się do wcześniejszych prac, jak m.in. Cavesa (1974), gdzie stwierdzono, że wzrost produktywności firm lokalnych koreluje pozytywnie ze wzrostem udziału kapitału zagranicznego w przemyśle. Fauzel i in. (2015), wykorzystując model VECM dla danych rocznych 1980-2010, badali występowanie efektów spillover w sektorze produkcyjnym na Mauritiusie. Wykazali, że BIZ w istotnym stopniu przyczyniały się do poprawy rynku pracy i TFP w długim okresie.

\section{OPIS ZMIENNYCH}

W badaniu wykorzystano roczne szeregi czasowe za lata 1997-2012 dla Polski. Dane pochodzą z bazy Eurostatu.

Tab. 1. Wykaz i charakterystyka rozważanych zmiennych

\begin{tabular}{|l|c|l|l|}
\hline \multicolumn{1}{|c|}{ Zmienna } & Jednostka & \multicolumn{1}{|c|}{ Opis } & \multicolumn{1}{|c|}{ Kod Eurostatu } \\
\hline GVA & $\begin{array}{c}\text { miliony } \\
\text { euro }\end{array}$ & $\begin{array}{l}\text { Wartość dodana brutto } \\
\text { w gospodarce (sektorze) }\end{array}$ & nama_10_gdp \\
\hline GFCFGDP & $\%$ & $\begin{array}{l}\text { Udział wartości nakładów brutto } \\
\text { na środki trwałe w gospodarce } \\
\text { (sektorze) w mln euro w cenach } \\
\text { bieżących względem PKB w mln } \\
\text { euro w cenach bieżących }\end{array}$ & $\begin{array}{l}\text { nama_10_an6 } \\
\text { nama_10_gdp }\end{array}$ \\
\hline
\end{tabular}




\begin{tabular}{|c|c|c|c|}
\hline FDIstockGDP & $\%$ & $\begin{array}{l}\text { Udział wartości skumulowanej } \\
\text { BIZ w mln euro w gospodarce } \\
\text { (sektorze) względem PKB w mln } \\
\text { euro w cenach bieżących }\end{array}$ & $\begin{array}{l}\text { bop_fdi_pos NACE Rev.1.1 } \\
\text { i } 2 \\
\text { nama_10_gdp }\end{array}$ \\
\hline HICP & $\%$ & Wskaźnik inflacji HICP & prc_hicp_aind \\
\hline OPENNES & $\%$ & $\begin{array}{l}\text { Iloraz sumy eksportu i importu } \\
\text { (dóbr i usług) w mln euro } \\
\text { w cenach bieżących względem } \\
\text { PKB w mln euro w cenach } \\
\text { bieżących }\end{array}$ & $\begin{array}{l}\text { tec00110 } \\
\text { nama_10_gdp }\end{array}$ \\
\hline NEERIndex & index & $\begin{array}{l}\text { Nominalny efektywny kurs } \\
\text { walutowy z głównymi } 42 \\
\text { partnerami handlowymi }\end{array}$ & ert_eff_ic_a] \\
\hline
\end{tabular}

Źródło: opracowanie własne na podstawie danych Eurostatu

Zmienną objaśnianą w modelu jest wartość dodana brutto w gospodarce (w sekcji przetwórstwa przemysłowego) GVA. Będzie ona regresowana względem udziału wartości nakładów brutto na środki trwałe w gospodarce (w sektorze przetwórczym) w stosunku do PKB, udziałem wartości skumulowanej BIZ w gospodarce (w przetwórstwie przemysłowym) względem PKB, wskaźnika inflacji, otwartości gospodarki (por. Edwards, 1998) oraz indeksu nominalnego efektywnego kursu walutowego.

Przez wartość dodaną brutto rozumie się wartość wszystkich wyrobów i usług wytworzonych przez wszystkie krajowe podmioty pomniejszoną o koszty związane z ich wytworzeniem. Wartość dodana brutto opisuje przyrost wartości dóbr w danym okresie.

Oczekuje się, że wzrost udziału kapitału zagranicznego w gospodarce (sekcji) powinien prowadzić do wzrostu wartości dodanej brutto w gospodarce (w sekcji). Podobnie relatywny wzrost nakładów na środki trwałe, przez m.in. zakup sprzętu, maszyn, budynków, fabryk, powinien pozytywnie oddziaływać na możliwości generowania wyższej wartości dodanej. Włączenie inflacji, otwartości gospodarki i kursu walutowego do modelu znajduje uzasadnienie w postulacie aproksymacji odpowiednio stabilności makroekonomicznej, powiązań z gospodarką światową oraz konkurencyjności gospodarki.

\section{SPECYFIKACJA MODELU}

Przyjęto następującą specyfikację modelu [1], która będzie podlegać estymacji z wykorzystaniem log-liniowej funkcji Cobba-Douglasa [2] w postaci zlinearyzowanej [3].

$$
\begin{aligned}
& G V A=f(G F C F G D P, F D I s t o c k G D P, H I C P, O P E N N E S, N E E R I n d e x)+\varepsilon \\
& G V A_{t}=\beta_{0} G F C F G D P_{t}^{\beta_{1}} \times F D I \text { stockGDP } P_{t}^{\beta_{2}} \times H I C P_{t}^{\beta_{3}} \times O^{O P E N N E S} S_{t}^{\beta_{4}} \times \\
& \times N E E R I n d e x_{t}^{\beta_{5}} \times u_{t}^{\varepsilon_{t}}
\end{aligned}
$$




$$
\begin{aligned}
& \ln G V A_{t}=\ln \beta_{0}+\beta_{1} \ln G F C G D P_{t}+\beta_{2} \ln F D \text { IstockGDP }+\beta_{3} \ln H I C P+ \\
& +\beta_{4} \operatorname{lnOPENNES}+\beta_{5} \ln N E E R I n d e x+\varepsilon_{t}
\end{aligned}
$$

Parametry $\beta_{1-5}$ wyrażają elastyczności zmiennych względem wartości dodanej brutto, umożliwiając tym samym interpretację w kategoriach procentowych.

\section{Procedura TESTOWANIA STACJONARNOŚCI}

W statystyce i ekonometrii test ADF-GLS (lub test DF-GLS) jest testem sprawdzającym obecność pierwiastka jednostkowego w szeregach czasowych. Został on opracowany przez Elliotta, Rothenberga i Stocka w 1992 roku jako modyfikacja rozszerzonego testu Dickey-Fullera $\left(\mathrm{ADF}^{4}\right)$.

$$
\begin{aligned}
& y_{t}=d_{t}+u_{t} \\
& u_{t}=\rho u_{t-1}+e_{t}
\end{aligned}
$$

$y_{\mathrm{t}}$ - szereg czasowy

$d_{\mathrm{t}}$ - trend deterministyczny

$u_{\mathrm{t}}-$ składnik stochastyczny

Jeśli $p$ jest bliskie 1, estymacja modelu będzie nieefektywna $\mathrm{z}$ uwagi na niestacjonarność $y_{\mathrm{t}}$ związaną np. z występowaniem trendu. W celu rozwiązania tego problemu zaproponowana została modyfikacja testu uwzględniająca różnicowanie szeregu czasowego.

Procedura testu ADF-GLS jest dwuetapowa. W pierwszym kroku z szeregu usuwana jest średnia (i ewentualnie trend) przez oszacowanie regresji szeregu względem stałej (i ewentualnie trendu) za pomocą estymatora UMNK (GLS). W kolejnym kroku reszty z pierwotnej regresji testowane są z wykorzystaniem testu ADF. Procedura ta ma na celu zwiększenie mocy testu ADF w przypadku procesów silnie autoregresyjnych.

\section{ProcedurA TESTOWANIA KOINTEGRACJI}

W przypadku niestacjonarnych zmiennych estymacja modeli typu VAR dla przyrostów zmiennych nie pozwala na wyodrębnienie tendencji długookresowych. Zgodnie z definicją Engle'a i Grangera szeregi czasowe $x_{\mathrm{t}}, y_{\mathrm{t}}$ są skointegrowane rzędu $d, b$, gdzie, $\mathrm{d} \geq \mathrm{b} \geq 0$, co zapisuje się jako $x_{\mathrm{t}}, y_{\mathrm{t}} \sim C I(d, b)$, gdy oba szeregi są zintegrowane rzędu $d\left(x_{\mathrm{t}}, y_{\mathrm{t}} \sim I(d)\right)$ oraz istnieje liniowa kombinacja tych zmiennych, tj. $\beta_{1} x_{\mathrm{t}}+\beta_{2} y_{\mathrm{t}}$, która jest zintegrowana rzędu $d-b$. Wtedy wektor $\left[\beta_{1} \beta_{2}\right]$ określany jest mianem wektora kointegrującego. Jednym $\mathrm{z}$ bardziej popularnych algorytmów badających kointegrację jest dwuetapowa procedura

\footnotetext{
${ }^{4}$ Procedura testowania w teście ADF: $\Delta y_{t}=\alpha+\beta t+\gamma y_{t-1}+\delta_{1} \Delta y_{t-1}+\cdots+\delta_{p-1} \Delta y_{t-p+1}+\varepsilon_{t}$
} 
Engle'a-Grangera (Engle, Granger, 1987: 251-256). Sprowadza się ona do oceny stacjonarności reszt z założonej relacji długookresowej równowagi. Podejście to jednak ma dwie istotne wady. Po pierwsze, w sytuacji gdy regresja obarczona była błędem, przenoszony jest on do drugiego etapu. Ponadto estymacja w tym podejściu wymaga jednoznacznego określenia, która zmienna występuje w roli zmiennej objaśnianej i objaśniającej. Proponuje się zatem częściej podejście Johansena (1988: 231-254), Johansena i Juseliusa (1990). W literaturze najczęściej spotykamy się z następującą postacią modelu VECM:

$$
\begin{gathered}
\Delta x_{t}=\Psi_{0} D_{t}+\Pi x_{t-1}+\sum_{i=1}^{k-1} \Pi_{i} \Delta_{x_{t-i}}+\epsilon_{t} \\
\Pi=\sum_{i=1}^{k} A_{i}-I \\
\Pi_{i}=-\sum_{j=i+1}^{k} A_{j}
\end{gathered}
$$

Johansen wykazał, że w przypadku wielowymiarowym w badaniu kointegracji możliwe jest posługiwanie się rzędem macierzy П. Jeśli macierz jest rzędu pierwszego, istnieje jeden wektor kointegrujący, a wyrażenie $\Pi x_{\mathrm{t}-1}$ stanowi czynnik korekty błędu, jeśli wyższego, to występuje więcej niż jeden wektor kointegrujący. W przypadku gdy rząd macierzy wynosi 0 , zasadna jest estymacja modelu VAR dla przyrostów zmiennych. Pełny rząd macierzy oznacza, że szeregi wektora $x_{\mathrm{t}}$ są stacjonarne, a model [6] jest nieograniczonym modelem VAR dla poziomów zmiennych. W badaniu rzędu macierzy $\Pi$ wykorzystywany jest fakt, że rząd macierzy jest równy liczbie jej niezerowych pierwiastków charakterystycznych. Jeśli rząd macierzy $\Pi$ wynosi $r$, to $r$ pierwszych pierwiastków charakterystycznych jest różnych od zera (Kusideł, 2000: 59).

W testowaniu kointegracji wykorzystywane są powszechnie dwa testy sprawdzające liczbę pierwiastków charakterystycznych, które są nieistotnie statystycznie różne od zera:

1. Statystyka śladu służąca do weryfikacji $H_{0}$, mówiącej, że liczba różnych od siebie wektorów kointegrujących jest mniejsza lub równa $r$.

$$
\lambda_{\text {trace }}(r)=-T \sum_{i=r+1}^{\prime \prime} \ln \left(1-\lambda_{i}\right)
$$

2. Statystyka maksymalnej wartości własnej służąca do weryfikacji $H_{A}$, mówiącej, że liczba wektorów kointegrujących wynosi $r$ wobec $H_{A}$, mówiącej, że jest ich $r+1$.

$$
\lambda_{\max }(r, r+1)=-T \ln \left(1-\lambda_{r+i}\right)
$$




\section{WYNIKI BADAŃ}

Przeprowadzone testy stacjonarności wskazują na niestacjonarność zmiennych oraz ich logarytmów (tab. 1). Próbkowe wartości statystyk nie przekraczały wartości krytycznych, co nie uprawniało do odrzucania $H_{0}$, mówiącej o występowaniu pierwiastka jednostkowego I(1). Wyniki uzyskane dla gospodarki ogółem oraz sektora przetwórczego (NACE:C) są zgodne, przy czym stwierdzono jedynie stacjonarność logarytmu udziału bezpośrednich inwestycji zagranicznych w sektorze przetwórczym względem PKB (tab. 2, 3).

Tab. 2. Wyniki testu ADF-GLS dla logarytmów zmiennych dla gospodarki

\begin{tabular}{|l|c|c|c|c|}
\hline \multicolumn{1}{|c|}{ Zmienna } & Type & ADF-GLS & Opóźnienia & Stacjonarność \\
\hline L_HICP & Const & $-1,25578$ & 5 & - \\
\hline L_OPENNES & Trend & $-1,92747$ & 5 & - \\
\hline L_NEERIndex & Const & $-0,423333$ & 5 & - \\
\hline L_GVA & Trend & $-2,98014$ & 5 & - \\
\hline L_GFCFGDP & Const & $-0,456598$ & 5 & - \\
\hline L_FDISTOCKGDP & Trend & $-1,23905$ & 5 & - \\
\hline L_RATE & Const & $-1,50018$ & 4 & - \\
\hline
\end{tabular}

Źródło: opracowanie własne

Tab. 3. Wyniki testu ADF-GLS dla logarytmów zmiennych w przetwórstwie przemysłowym

\begin{tabular}{|l|c|c|c|c|}
\hline \multicolumn{1}{|c|}{ Zmienna } & Type & ADF-GLS & Opóźnienia & Stacjonarność \\
\hline L_HICP & Const & $-1,25578$ & 5 & - \\
\hline L_OPENNES & Trend & $-1,92747$ & 5 & - \\
\hline L_NEERIndex & Const & $-0,423333$ & 5 & - \\
\hline L_GVA & Trend & $-2,14635$ & 5 & - \\
\hline L_GFCFGDP & Trend & $-3,26892$ & 5 & + \\
\hline L_FDISTOCKGDP & Trend & $-1,29938$ & 5 & - \\
\hline L_RATE & Trend & $-2,0884$ & 4 & - \\
\hline
\end{tabular}

Źródło: opracowanie własne

W przypadku całej gospodarki zasadne jest przyjęcie dwóch opóźnień w modelu VAR w modelowaniu zależności krótkookresowych pomiędzy udziałem wartości skumulowanej bezpośrednich inwestycji zagranicznych w PKB względem generowanej wartości dodanej brutto w gospodarce ogółem (tab. 4, 5). Analogiczne testy przeprowadzone dla sektora przetwórczego wskazują na wybór 1 opóźnienia.

Tab. 4. Kryteria informacyjne przy wyborze rzędu opóźnień modelu VAR dla gospodarki

\begin{tabular}{|c|c|c|c|c|c|}
\hline Opóźnienia & $\log \mathrm{L}$ & $\mathrm{p}(\mathrm{LR})$ & $\mathrm{AIC}$ & $\mathrm{BIC}$ & HQC \\
\hline 1 & 28,49607 & & $-3,460933$ & $-3,200188$ & $-3,514528$ \\
\hline 2 & 36,46407 & 0,00311 & $-4,071396^{*}$ & $-3,636819^{*}$ & $-4,160721^{*}$ \\
\hline 3 & 38,95275 & 0,28963 & $-3,838885$ & $-3,230478$ & $-3,963940$ \\
\hline
\end{tabular}

Źródło: opracowanie własne 
Tab. 5. Kryteria informacyjne przy wyborze rzędu opóźnień modelu dla przetwórstwa przemysłowego

\begin{tabular}{|c|c|c|c|c|c|}
\hline Opóźnienia & $\operatorname{logL}$ & $\mathrm{p}(\mathrm{LR})$ & $\mathrm{AIC}$ & $\mathrm{BIC}$ & HQC \\
\hline 1 & 33,35287 & & $-4,208134^{\star}$ & $-3,947388^{\star}$ & $-4,261729^{\star}$ \\
\hline 2 & 34,64918 & 0,62813 & $-3,792181$ & $-3,357605$ & $-3,881506$ \\
\hline 3 & 36,21584 & 0,53577 & $-3,417821$ & $-2,809414$ & $-3,542876$ \\
\hline
\end{tabular}

Źródło: opracowanie własne

Wyniki testów kointegracji bazujące na statystyce śladu i maksymalnej wartości, własnej zarówno dla gospodarki ogółem, jak i sektora przetwórczego, wskazują na występowanie relacji długookresowej pomiędzy wartością dodaną brutto a udziałem wartości skumulowanej BIZ w produkcie krajowym brutto. W oparciu o testy odrzucana jest hipoteza zerowa zakładająca brak relacji kointegrującej (tab. 6, 7).

Tab. 6. Wyniki testów kointegracji 1_GVA i 1_FDIstockGDP dla gospodarki

\begin{tabular}{|c|c|c|c|c|c|}
\hline Rząd & Wartość własna & Trace Stat. & Prob & Test Lmax & Prob. \\
\hline 0 & 0,75285 & 20,647 & 0,0066 & 19,569 & 0,0054 \\
\hline 1 & 0,074123 & 1,0782 & 0,2991 & 1,0782 & 0,2991 \\
\hline
\end{tabular}

Źródło: opracowanie własne

Tab. 7. Wyniki testów kointegracji 1_GVA i 1_FDIstockGDP dla przetwórstwa przemysłowego

\begin{tabular}{|c|c|c|c|c|c|}
\hline Rząd & $\begin{array}{c}\text { Wartość } \\
\text { własna }\end{array}$ & Trace Stat. & Prob & Test Lmax & Prob. \\
\hline 0 & 0,73756 & 18,587 & 0,0151 & 17,391 & 0,0137 \\
\hline 1 & 0,087888 & 1,1959 & 0,2741 & 1,1959 & 0,2741 \\
\hline
\end{tabular}

Źródło: opracowanie własne

Biorąc pod uwagę testy diagnostyczne, niemal 95\% zmienności wartości dodanej brutto jest wyjaśnione przez model z czterema zmiennymi wyrażającymi stabilność gospodarki (inflacja), jej otwartość (iloraz sumy eksportu i importu względem PKB), nominalny efektywny kurs walutowy oraz relatywne zaangażowanie inwestorów zagranicznych. Przyjęta postać funkcyjna w świetle testów RESET okazała się właściwa, a reszty z modelu posiadają pożądane własności (normalność, brak autokorelacji, homoskedastycznosć). Stwierdza się, że w ślad za jednoprocentowym wzrostem udziału wartości skumulowanej BIZ w PKB wartość dodana brutto w gospodarce wzrasta o $0,31 \%$. Wzrost otwartości gospodarki o $1 \%$ prowadzi do niemal $1 \%$ zmiany w GVA, podczas gdy wzrost indeksu nominalnego efektywnego kursu walutowego prowadzi do ponadproporcjonalnego wzrostu wartości dodanej brutto (tab. 8). Wyniki te stanowią wsparcie dla wcześniejszych, przeprowadzonych dla innych gospodarek (Chandran, Krishnan, 2008; Faruq, 2012; Iddrisu 2015). 
Tab. 8. Wyniki regresji liniowej dla gospodarki, zmienna objaśniana 1_GVA

\begin{tabular}{|l|r|r|r|c|}
\hline \multicolumn{1}{|c|}{ Zmienna } & Oszacowanie & \multicolumn{1}{c|}{ Błąd. St. } & Stat. t. & Prob. \\
\hline const & 1,5828800 & 1,38025 & 1,1468 & 0,27579 \\
\hline 1_HICP & 0,0790365 & 0,0219249 & 3,6049 & 0,00413 \\
\hline 1_OPENNES & 0,980264 & 0,2049060 & 4,7840 & 0,00057 \\
\hline 1_NEERIndex & 1,180130 & 0,2914090 & 4,0497 & 0,00192 \\
\hline 1_FDIstockGDP & 0,308426 & 0,0852120 & 3,6195 & 0,00403 \\
\hline \multicolumn{5}{|c|}{ Testy diagnostyczne } \\
\hline R-kwadrat & 0,966671 & & & \\
\hline Skorygowany R-kwadrat & 0,954551 & & & \\
\hline Statystyka F & 137,3531 & & & \\
\hline Prob(F-statistic) & $2,61 \mathrm{e}-09$ & & & \\
\hline Statystyka Durbin Watson & 1,278990 & & & \\
\hline $\begin{array}{l}\text { Test seryjnej autokorelacji LM Test } \\
\text { Prob. }\end{array}$ & 0,195328 & & & \\
\hline Test normalności Chi ${ }^{2}$ Prob. & 0,509059 & & & \\
\hline $\begin{array}{l}\text { Test heteroskedastyczności White } \\
\text { Prob. }\end{array}$ & 0,347942 & & & \\
\hline
\end{tabular}

Źródło: opracowanie własne

W celu oszacowania analogicznych zależności względem GVA na poziomie sektora przetwórczego przedstawiono je z wykorzystaniem dwóch regresji (tab. 8 i 9) $)^{5}$. Przyjęta postać funkcyjna w świetle testów RESET okazała się również właściwa, a reszty z modelu posiadają pożądane własności (normalność, brak autokorelacji, homoskedastycznosć). Zauważono, że przy jednoprocentowym wzroście udziału wartości skumulowanej BIZ w PKB wartość dodana brutto $\mathrm{w}$ gospodarce wzrasta o 0,69\% (ponad dwukrotnie więcej niż dla gospodarki ogółem). Wzrost otwartości gospodarki o 1\% prowadzi do niemal 1,7\% zmiany w GVA, podczas gdy wzrost indeksu nominalnego efektywnego kursu walutowego prowadzi do zauważalnego wzrostu wartości dodanej brutto. Znaczenie inflacji, choć istotne statystycznie, uznać można za relatywnie niewielkie.

Tab. 9. Wyniki regresji liniowej dla przetwórstwa przemysłowego:zmienna objaśniana1_GVA(model 1)

\begin{tabular}{|l|r|r|r|c|}
\hline \multicolumn{1}{|c|}{ Zmienna } & Oszacowanie & \multicolumn{1}{c|}{ Błąd. St. } & \multicolumn{1}{c|}{ Stat. t. } & Prob. \\
\hline const & $-0,687275$ & 1,02544 & $-0,6702$ & 0,51541 \\
\hline 1_HICP & 0,107906 & 0,015549 & 6,9397 & 0,00002 \\
\hline
\end{tabular}

${ }^{5}$ Szacunków dokonywano oddzielnie z uwagi na wysoki stopień skorelowania zmiennych OPENNES i FDIstockGDP implikujących współliniowość. O ile zauważalna jest silna pozytywna korelacja tych zmiennych z GVA, o tyle z uwagi na niespełnienie założeń stochastycznych model 2 (tab. 8) nie był przedmiotem dalszych rozważań. 


\begin{tabular}{|l|r|r|r|r|}
\hline 1_OPENNES & 1,70466 & 0,0900873 & 18,9223 & 0,00001 \\
\hline 1_NEERIndex & 0,850035 & 0,256157 & 3,3184 & 0,00613 \\
\hline \multicolumn{4}{|c|}{ Testy diagnostyczne } & \\
\hline R-kwadrat & 0,953683 & & & \\
\hline Skorygowany R-kwadrat & 0,942104 & & & \\
\hline Statystyka F & 224,5337 & & & \\
\hline Prob(F-statistic) & $8,37 \mathrm{e}-11$ & & & \\
\hline Statystyka Durbin Watson & 2,482855 & & & \\
\hline $\begin{array}{l}\text { Test seryjnej autokorelacji LM Test } \\
\text { Prob. }\end{array}$ & 0,267695 & & & \\
\hline Test normalności Chi ${ }^{2}$ Prob. & 0,971115 & & & \\
\hline $\begin{array}{l}\text { Test heteroskedastycznosci White } \\
\text { Prob. }\end{array}$ & 0,158617 & & & \\
\hline
\end{tabular}

Źródło: opracowanie własne

Tab. 10. Wyniki regresji liniowej dla przetwórstwa przemysłowego: zmienna objaśniana 1_GVA (model 2)

\begin{tabular}{|l|c|c|c|c|}
\hline \multicolumn{1}{|c|}{ Zmienna } & Oszacowanie & Błąd. St. & Stat. t. & Prob. \\
\hline const & 2,14138 & 2,70669 & 0,7911 & 0,44422 \\
\hline 1_NEERIndex & 1,47017 & 0,60718 & 2,4213 & 0,03224 \\
\hline 1_HICP & 0,11792 & 0,06065 & 1,9444 & 0,07566 \\
\hline 1_FDIstockGDP & 0,69088 & 0,13120 & 5,2659 & 0,00020 \\
\hline \multicolumn{5}{|c|}{ Testy diagnostyczne } \\
\hline R-kwadrat & 0,816157 & & \\
\hline Skorygowany R-kwadrat & 0,770197 & & & \\
\hline Statystyka F & 17,75773 & & & \\
\hline Prob(F-statistic) & 0,000104 & & & \\
\hline Statystyka Durbin Watson & 0,802375 & & & \\
\hline $\begin{array}{l}\text { Test seryjnej autokorelacji LM Test } \\
\text { Prob. }\end{array}$ & 0,012384 & & & \\
\hline Test normalności Chi ${ }^{2}$ Prob. & 0,043392 & & & \\
\hline $\begin{array}{l}\text { Test heteroskedastyczności White } \\
\text { Prob. }\end{array}$ & 0,321381 & & & \\
\hline
\end{tabular}

Źródło: opracowanie własne

Oszacowanie modelu wektorowej autoregresji z mechanizmem korekty błędu wskazuje na występowanie pozytywnego istotnego statystycznie opóźnionego o dwa okresy wpływu wzrostu zaangażowania kapitału zagranicznego w gospodarce kraju goszczącego na przyrost wartości dodanej brutto. Wysoka wartość parametru EC1 oznacza, że powrót do ścieżki długookresowej relacji następuje już po pierwszym roku od wystąpienia zachwiania równowagi (tab. 9). W tab. 10 przedstawiono wyniki estymacji, z których wynika, że opóźniony przyrost udziału wartości skumulowanej BIZ w PKB jest przyczyną w sensie Grangera (1969) 
dla przyrostów wartości dodanej brutto. Jednocześnie widoczne jest, że redukcja modelu o zmienną OPENNES (silnie skorelowaną z FDIstockGDP) prowadzi do wniosków, że dodatnie zmiany wartości dodanej brutto, jak i wzrost zaangażowania kapitału zagranicznego w kraju goszczącym sprzed dwóch okresów, towarzyszą obecnym pozytywnym zmianom wartości dodanej brutto. Relatywnie niewielkie, ale pozytywne, znaczenie dla GVA ma poziom inflacji, co stwierdzono już wcześniej. Analizując równanie zmian w wartości dodanej brutto, zauważamy, że wzrost udziału skumulowanej wartości BIZ w sektorze przetwórczym w PKB w okresie poprzednim, jak również wzrost nakładów brutto na środki trwałe w stosunku do PKB w okresie $t-1$, prowadzą do wzrostu wartości dodanej brutto w sektorze przetwórczym obecnie. Zauważalny jest także istotny pozytywny i porównywalny wpływ postępującego otwarcia gospodarki polskiej oraz aprecjacji złotego na wzrost wartości dodanej brutto (tab. 11).

Tab. 11. Wyniki estymacji modelu VECM dla gospodarki: równanie d_1_GVA (model 1)

\begin{tabular}{|l|c|r|r|c|}
\hline \multicolumn{1}{|c|}{ Zmienna } & Oszacowanie & \multicolumn{1}{c|}{ Błąd. St. } & \multicolumn{1}{c|}{ Stat. t. } & \multicolumn{1}{c|}{ Prob. } \\
\hline const & 8,87128 & 3,41195 & 2,6001 & 0,08037 \\
\hline d_1_GVA_1 & $-0,66416$ & 0,357127 & $-1,8597$ & 0,15987 \\
\hline d_1_GVA_2 & 0,277267 & 0,129501 & 2,141 & 0,12173 \\
\hline d_1_FDIstockGDP_1 & $-0,37055$ & 0,304847 & $-1,2155$ & 0,31109 \\
\hline d_1_FDIstockGDP_2 & 0,406511 & 0,152809 & 2,6603 & 0,07632 \\
\hline 1_HICP & 0,036287 & 0,028002 & 1,2958 & 0,28572 \\
\hline 1_NEERIndex & 0,073711 & 0,356883 & 0,2065 & 0,84959 \\
\hline 1_OPENNES & $-0,86205$ & 0,557985 & $-1,5449$ & 0,22007 \\
\hline 1_GFCF & 0,419726 & 0,260323 & 1,6123 & 0,20529 \\
\hline EC1 & $-1,07554$ & 0,283142 & $-3,7986$ & 0,03204 \\
\hline R-kwadrat & 0,982142 & & & \\
\hline Skorygowany R-kwadrat & 0,928569 & & & \\
\hline LR & 65,150823 & & & \\
\hline
\end{tabular}

Źródło: opracowanie własne

Tab. 12. Wyniki estymacji modelu VECM dla gospodarki: równanie d_1_GVA (model 2)

\begin{tabular}{|l|r|r|r|c|}
\hline \multicolumn{1}{|c|}{ Zmienna } & Oszacowanie & \multicolumn{1}{c|}{ Błąd. St. } & Stat. t. & \multicolumn{1}{c|}{ Prob. } \\
\hline const & 4,42533 & 1,93327 & 2,289 & 0,0707 \\
\hline d_1_GVA_1 & $-0,227385$ & 0,249058 & $-0,913$ & 0,4031 \\
\hline d_1_GVA_2 & 0,371409 & 0,144277 & 2,574 & 0,0498 \\
\hline d_1_FDIstockGDP_1 & 0,109267 & 0,113193 & 0,9653 & 0,3787 \\
\hline d_1_FDIstockGDP_2 & 0,302322 & 0,143108 & 2,113 & 0,0883 \\
\hline 1_HICP & 0,072212 & 0,017003 & 4,247 & 0,0081 \\
\hline 1_NEERIndex & 0,304105 & 0,261074 & 1,165 & 0,2966 \\
\hline
\end{tabular}




\begin{tabular}{|l|r|r|r|r|}
\hline EC1 & $-0,648868$ & 0,129037 & 5,029 & 0,004 \\
\hline R-kwadrat & 0,96233 & & & \\
\hline Skorygowany R-kwadrat & 0,909592 & & & \\
\hline LR & 60,471711 & & & \\
\hline
\end{tabular}

Źródło: opracowanie własne

Tab. 13. Wyniki estymacji modelu VECM dla przetwórstwa przemysłowego, równanie d_1_GVA

\begin{tabular}{|l|c|r|r|r|}
\hline \multicolumn{1}{|c|}{ Zmienna } & Oszacowanie & Błąd. St. & Stat. t. & Prob. \\
\hline const & $-3,9513$ & 1,03516 & $-3,817$ & 0,0088 \\
\hline d_1_GVA_1 & 0,078905 & 0,198535 & 0,3974 & 0,7048 \\
\hline d_1_FDIstockGDP_1 & 0,324676 & 0,08778 & 3,699 & 0,0101 \\
\hline d_1_GFCFGDP_1 & 0,287392 & 0,139154 & 2,065 & 0,0844 \\
\hline 1_HICP & 0,011809 & 0,024294 & 0,4861 & 0,6441 \\
\hline 1_OPENNES & 0,835917 & 0,245277 & 3,408 & 0,0144 \\
\hline 1_NEERIndex & 0,809555 & 0,27002 & 2,998 & 0,0241 \\
\hline EC1 & $-0,234270$ & 0,087039 & $-2,692$ & 0,036 \\
\hline R-kwadrat & 0,880690 & & & \\
\hline Skorygowany R-kwadrat & 0,741495 & & & \\
\hline LR & 90,886945 & & & \\
\hline
\end{tabular}

Źródło: opracowanie własne

\section{KonKLUZJE}

Uzyskane wyniki empiryczne potwierdzają zasadność rozpatrywania efektów obecności bezpośrednich inwestycji zagranicznych z punktu widzenia poszczególnych sektorów gospodarki. Zauważalne są istotne różnice w sile oddziaływania BIZ na wartość dodaną w polskiej gospodarce i sektorze przetwórczym. Co więcej, widoczne są różnice w opóźnionym wpływie obecności kapitału zagranicznego na wartość dodaną. Takie czynniki, jak nominalny efektywny kurs walutowy, wskaźnik inflacji czy relatywne nakłady na środki trwałe, również stanowią istotne determinanty produktywności gospodarki. Przeprowadzone testy kointegracji wskazują na występowanie relacji długookresowej istniejącej pomiędzy zmiennymi GVA oraz FDIstockGDP, aczkolwiek wyrażają się one jednocześnie bardzo różnym tempem powrotu do ścieżki długookresowego wzrostu po wytrąceniu układu z równowagi zaburzeniem losowym. Przeprowadzone badanie wiązało się z istotnymi trudnościami W związku z relatywnie niską liczbą stopni swobody, uniemożliwiającą estymację modeli równowagi długookresowej o bardziej rozbudowanym wektorze zmiennych objaśnianych $x_{\mathrm{t}}$, co z kolei implikowało rozpatrywanie pozostałych zmiennych jako egzogenicznych.

Postuluje się przeprowadzenie dalszych, pogłębionych badań dla wszystkich sektorów NACE dla danych o niższej agregacji (kwartalnej), z uwzględnieniem szeregu strukturalnych 
i instyutucjonalnych zmiennych kontrolnych wyrażających zdolności absorbcyjne. Ponadto w dalszych badaniach autor oceni, na ile uzyskane wyniki są odporne przy rozszerzeniu modeli o czynniki aproksymujące nakłady pracy oraz postęp technologiczny, co jest praktyką powszechną w badaniach nad modelowaniem produktywności i wzrostu gospodarczego

\section{Literatura \\ References}

Alfaro, L., (2003). Foreign Direct Investment and Growth: Does the Sector Matter? Harvard: Harvard University, Harvard Business School.

Balcerzak, A.P., Żurek, M. (2010). Analiza wpływu bezpośrednich inwestycji zagranicznych na PKB i stopę bezrobocia w Polsce w latach 1995-2010 za pomocą modelu VAR. Roczniki Naukowe Wyższej Szkoły Informatyki i Ekonomii Towarzystwa Wiedzy Powszechnej, 1-2.

Brodzicki T., Ciołek, D. (2010). Przestrzenno-czasowa analiza determinant lokalizacji przemystu przetwórczego i ushug rynkowych w polskich regionach. Konferencja naukowa „Ekonometria przestrzenna i regionalne analizy ekonomiczne". Łódź: Uniwersytet Łódzki.

Brodzicki, T., Ciołek, D. (2014). Determinanty lokalizacji działalności gospodarczej w polskich regionach. W: K. Gawlikowska-Hueckel, J. Szlachta. Wrażliwość polskich regionów na wyzwania wspótczesnej gospodarki: implikacje dla polityki rozwoju regionalnego. Warszawa: Wolters Kluwer, 299-322.

Carkovic, M., Levine, R. (2002). Does foreign direct investment accelerate economic growth? Minnesota: University of Minnesota Department of Finance Working Paper.

Caves, R. (1974). Multinational firms, competition, and productivity in host country markets. Economica, 41(162), 176-193.

Chandran, V.G.R., Krishnan, G. (2008). Foreign Direct Investment and Manufacturing Growth: The Malaysian Experience. International Business Research, 1(3).

Choong, C.K., Baharumshah, A.Z., Yusop, Z., Habibullah, M.S. (2010). Private Capital flows, stock market and economic growth in developed and developing Countries: a comparative analysis. Japan and the World Economy, 22, 107-117.

Ciołek, D., Golejewska, A. (2005). Wpływ bezpośrednich inwestycji zagranicznych na polski przemyst przetwórczy $w$ oparciu o dane panelowe z lat 1993-2002. Materiały zgłoszone na IX Ogólnopolskie Seminarium Naukowe. Toruń: Wydawnictwo Uniwersytetu Mikołaja Kopernika.

Ciołek, D., Golejewska, A. (2006). Dyfuzja produktywności jako efekt pośredni FDI w polskim przemyśle przetwórczym w latach 1993-2002. Ekonometria, 3, 41-52.

Ciołek, D., Umiński, S. (2007). Jak mierzyć wpływ bezpośrednich inwestycji zagranicznych na produktywność przemysłu w Polsce? Prace i Materiały Wydziału Zarzadzania Uniwersytetu Gdańskiego, 5, 107-125

Djankov, S., B. Hoekman, B. (2000). Foreign Investment and Productivity Growth in Czech Enterprises. World Bank Economic Review, 14, 49-64.

Edwards, S. (1998). Openness, Productivity and Growth: What Do We Really Know? Economic Journal, 108, 383-398.

Engle, R.F., Granger, C.W.J. (1987). Cointegration and Error Correction: Representation, Estimation and Testing. Econometrica, 55(2).

Faruq, H. (2012). Multinational presence and the export participation of local firms in Ghana. Applied Economics Letters, 19, 1515-1519.

Fauzel, S., Seetanah, B., Sannasee, R.V. (2015). Productivity Spillovers of FDI in the Manufacturing Sector of Mauritius. Evidence from a Dynamic Framework. The Journal of Developing Areas, 49(2). 
Frey, M. (1992). Foreign Direct Investment in a Macroeconomic Framework: Finance, Efficiency, Incentives and Distortions. Birmingham: International Financial Group, University of Birmingham.

Girma, S., Görg, H. (2007). Multinationals' Productivity Advantage: Scale Or Technology? Economic Inquiry, 45(2), 350-362.

Golejewska, A. (2009). Are There Labour Productivity Spillovers from Foreign Direct Investment? Evidence from the Polish Manufacturing Sector, 1993-2007. Yearbook of Polish European Studies. Uniwersytet Warszawski: Centre for Europe, 149-162.

Granger, C.W.J. (1969). Investigating Casual Relations by Econometric Models and Cross-Spectral Methods. Econometrica, 37.

Gurgul, H., Lach, Ł. (2009). Związki przyczynowe pomiędzy bezpośrednimi inwestycjami zagranicznymi w Polsce a podstawowymi wskaźnikami makroekonomicznymi. Ekonomia Menedżerska, 6, 77-91

Hassan, M. (2004). FDI, Information Technology and Economic Growth in the MENA Region. Working Paper, 10. Economic Research Forum. Pozyskano z http://www.erf.org.eg/CMS/getfile. php?id $=602$

Iddrisu, A.A., Adam, B., Halidu, B.O. (2015). The influence of foreign direct investment (FDI) on the productivity of the industrial sector in Ghana. International Journal of Academic Research in Accounting, Finance and Management Sciences, 5(3), 1-13.

Javorcik, B. (2004). Does foreign direct investment increase the productivity of domestic firms? In search of spillovers through backward linkages. American Economic Review, 94(3), 605-627.

Johansen, S. (1988). Statistical Analysis of Cointegration Vectors. Journal of Economic Dynamics and Control, 12(2-3).

Johansen, S., Juselius, K. (1990). Maximum Likelihood Estimation and Inference on Cointegration with Applications to the Demand for Money. Oxford Bulletin of Economics and Statistics, 52(2), $169-210$.

Kolasa, M. (2007). How does FDI inflow affect productivity of domestic firms? The role of horizontal and vertical spillovers, absorptive capacity and competition. Materialy $i$ Studia NBP, 42.

Konings, J. (2001). The effects of foreign direct investment on domestic firms. Evidence from firm-level panel data in emerging economies. Economics of Transition, 9(3), 619-633.

Kusideł, E. (2000). Modele wektorowo-autoregresyjne VAR. Metodologia i zastosowania. W: B. Suchecki (red.). Dane panelowe i modelowanie wielowymiarowe $w$ badaniach ekonomicznych. Łódź: Wydawnictwo Absolwent.

Kwiatkowski, D., Phillips, P.C., Schmidt, P., Shin, Y. (1992). Testing the Null Hypothesis of Stationarity against the Alternative of a Unit Root. Journal of Econometrics, 54.

Marona, B., Bieniek, A. (2013). Wykorzystanie modelu VECM do analizy wpływu bezpośrednich inwestycji zagranicznych na gospodarkę Polski w latach 1996-2010. Acta Universitatis Nicolai Copernici, Ekonomia, XLIV, 2.

Pawłowska, E., Wojciechowski, L. (2015). Znaczenie napływu BIZ w kontekście wzrostu i rozwoju gospodarczego na przykładzie krajów Grupy Wyszechradzkiej. W: K. Woźniak (red.). Narzędzia analityczne w naukach ekonomicznych. Kraków: Wydawnictwo Mfiles, 193-202.

Phillips, P.C., Perron, P. (1988). Testing for a unit root in time series regression. Biometrika, 75(2).

Rachwał, T. (2000). Wpływ inwestycji zagranicznych na zmiany w funkcjonowaniu Huty Szkła Jarosław S.A. w procesie transformacji gospodarczej. Rocznik Naukowo-Dydaktyczny AP w Krakowie, 209.

Samimi, A.J., Zeinab, R., Faezeh, A. (2010). Growth and FDI in OIC Countries. Australian Journal of Basic and Applied Sciences, 4(10), 4883-4885.

Sgard, J. (2001). Direct Foreign Investments and Productivity Growth in Hungarian Firms, 1992-1999. CEPII Working Paper, 1/19. 
Szczepkowska-Flis, A. (2006). Wpływ bezpośrednich inwestycji zagranicznych na produktywność w polskim przetwórstwie przemysłowym. W: D. Kopycińska (red. nauk.). Zachowania rynkowe gospodarstw domowych i przedsiębiorstw $w$ okresie transformacji systemowej $w$ Polsce. Szczecin: Print Group Daniel Krzanowski, 158-170.

Szczepkowska-Flis, A. (2008). Wewnątrzbranżowe efekty spillover bezpośrednich inwestycji zagranicznych. Ruch prawniczy, ekonomiczny i socjologiczny, 1, 171-184.

Wach, K., Wojciechowski, L. (2015). Determinants of Inward FDI into Four Visegrad Countries: Empirical Evidence based on Panel Data for the years 2000-2012. Economics and Business Review, under press Poznan University of Economics.

World Investment Report 2015 (2015) (2016, 8 stycznia). UNCTAD. Pozyskano z unctad.org/en/ PublicationsLibrary/wir2015_en.pdf

Żukowska-Gagelman, K. (2000). Productivity spillovers from foreign direct investment in Poland. Economic Systems, 24(3), 223-256.

Liwiusz Wojciechowski, mgr, doktorant na Uniwersytecie Ekonomicznym w Krakowie. Uzyskał podwójny tytuł magistra nauk ekonomicznych ze specjalnością finanse międzynarodowe i bankowość oraz informatyka i ekonometria. Autor lub współautor 11 artykułów naukowych opublikowanych w czasopismach i monografiach oraz referent na 10 konferencjach. Uczestnik międzynarodowego projektu badawczego oraz stypendiów zagranicznych CEEPUS (Słowacja) oraz TFAS (Czechy).

Liwiusz Wojciechowski, Ms.C., Ph.D. student, Cracow University of Economics, Faculty of Economics and International Relations, Department of Entrepreneurship and Innovation. He is Ph.D. student at the Cracow University of Economics. Ms.C. in International Finance and Banking and Computer Science and Econometrics, the autor or coauthor of 11 scientific articles in journales, chapters in books and conference papers, participant of international research project (Patterns of Business Internationalization in Visegrad Countries - In Search for Regional Specifics) and scholarships ERASMUS (Slovakia), TFAS (Czech Republic).

\section{Adres/address:}

Uniwersytet Ekonomiczny w Krakowie

Wydział Ekonomii i Stosunków Międzynarodowych

Katedra Przedsiębiorczości i Innowacji

ul. Rakowicka 27, 31-510 Kraków, Polska

e-mail: Liwiusz.w@o2.p1 